\title{
Combining eco-efficiency and eco-effectiveness for continuous loop beverage packaging systems: learnings from the Carlsberg Circular Community
}

Niero, Monia; Hauschild, Michael Zwicky; Hoffmeyer, Simon Boas; Olsen, Stig Irving

Published in:

Journal of Industrial Ecology

Link to article, DOI:

10.1111/jiec.12554

Publication date:

2017

Document Version

Peer reviewed version

Link back to DTU Orbit

Citation (APA):

Niero, M., Hauschild, M. Z., Hoffmeyer, S. B., \& Olsen, S. I. (2017). Combining eco-efficiency and ecoeffectiveness for continuous loop beverage packaging systems: learnings from the Carlsberg Circular Community. Journal of Industrial Ecology, 21(3), 742-753. https://doi.org/10.1111/jiec.12554

\section{General rights}

Copyright and moral rights for the publications made accessible in the public portal are retained by the authors and/or other copyright owners and it is a condition of accessing publications that users recognise and abide by the legal requirements associated with these rights.

- Users may download and print one copy of any publication from the public portal for the purpose of private study or research.

- You may not further distribute the material or use it for any profit-making activity or commercial gain

- You may freely distribute the URL identifying the publication in the public portal 
1 Journal of Industrial Ecology

2 Special Issue: Exploring the Circular Economy

3 Type of article: Applications and Implementation

4

5 Combining eco-efficiency and eco-effectiveness for continuous loop beverage

6 packaging systems: learnings from the Carlsberg Circular Community

7

8 Monia Niero $^{1 *}$, Michael Zwicky Hauschild ${ }^{1}$, Simon Boas Hoffmeyer ${ }^{2}$, Stig Irving Olsen ${ }^{1}$

$9 \quad{ }^{1}$ Division for Quantitative Sustainability Assessment (QSA), Department of Management

10 Engineering, Technical University of Denmark, Produktionstorvet Building 424, 2800 Kgs. Lyngby

11 (Denmark)

$12{ }^{2}$ Group Corporate Affairs, Carlsberg Breweries A/S, Ny Carlsberg Vej 100, 1799 Copenhagen V

13 (Denmark)

14

$15{ }^{*}$ To whom correspondence should be addressed: monni@dtu.dk; Tel.: +45 45251640 


\section{Summary}

Eco-efficiency, i.e. increasing value while reducing resource use and pollution, can with advantage be combined with eco-effectiveness, i.e. maximizing the benefits to ecological and economical systems, to address the challenges posed by the circular economy in the design of circular industrial systems. We present a framework combining Life Cycle Assessment (LCA) and the Cradle to Cradle $^{\circledR}$ (C2C) certification program for the development of continuous loop packaging systems, which was conceived for aluminum cans in the context of the Carlsberg Circular Community. As a first step, the environmentally optimal beverage packaging life cycle scenario is identified, both in terms of defined use and re-use. Secondly the limiting factors are identified for the continuous use of materials in multiple loops, meeting the two requirements in the $\mathrm{C} 2 \mathrm{C}$ certification process that address the material level (i.e. "material health" and "material reutilization" criteria) and the "renewable energy" criterion. Then, alternative scenarios are built to meet $\mathrm{C} 2 \mathrm{C}$ certification criteria, and LCA is used to quantify the environmental impacts of the resulting improvement strategies, e.g. change in material composition, in order to guide the identification of the optimal scenario from an eco-efficiency point of view. Finally, the business perspective is addressed by assessing the potential for a green value network business model for a closed-loop supply. The outcome is a list of prioritized actions needed to implement the most efficient and effective "upcycling" strategy for the beverage packaging, both from an environmental and economic point of view. In the case of the aluminum cans the main recommendation from both the LCA and $\mathrm{C} 2 \mathrm{C}$ perspective is to ensure a system that enables can-to-can recycling.

Keywords: circular economy, life cycle assessment (LCA), cradle-to-cradle, business models, recycling, resource management 


\section{$<$ heading level 1 $>$ Introduction}

Most of the initiatives developed at international level to tackle resource scarcity and sustainable production and consumption aim at a shift towards a resource-efficient and low-carbon economy (e.g. UNEP 2011). Their rationale is based on decoupling economic growth from resource use and reducing the adverse environmental impacts of products and services, while also meeting human needs and improving well-being (UNEP 2011). The circular economy, defined as a restorative or regenerative industrial system by intention and design (EMF 2013), has recently been proposed as a solution for this challenge by the European Commission (EC 2015).

High priority in the circular economy agenda is given to the packaging sector (EMF 2013) and to packaging waste management (EC 2015). Packaging is by its nature transient; most one-way packaging is discarded after use, entering the waste stream after a use period of typically less than a year (Hopewell et al. 2009). Companies in the beverage packaging sector were among the pioneers in the implementation of environmental sustainability strategies in their business. The very first studies of the direct and indirect use of energy associated with the life cycle of products regarded indeed the production of beverage containers (Hannon 1972). During the years, many initiatives have tried to address the issue of sustainability for packaging, e.g. the Australian Sustainable Packaging Alliance (Sustainable Packaging Alliance 2002) and the Sustainable Packaging Coalition (Greenblue 2011). As mentioned by Wever and Vogtländer (2013), the traditional approach to packaging and sustainability has been based on the use of Life Cycle Assessment (LCA). LCA is the most widespread tool able to quantify improvements in terms of eco-efficiency, i.e. increasing value while reducing resource use and pollution (Bjørn and Hauschild 2013). Due to its systemic approach defined by ISO 14040-44 standards (ISO 2006a, 2006b), LCA provides valuable support in integrating environmental sustainability targets into design, innovation and evaluation of products (Sala et al. 2012). LCA results provide the background for identification of potential 
burden shifting and optimization opportunities, thanks to the comprehensive assessment of all potential environmental impacts connected with a product system. Yet being an eco-efficiency inspired tool, LCA quantifies the environmental footprint of products or services and identifies reduction opportunities through comparison of scenarios for product system optimizations with the current baseline systems (Bjørn and Hauschild, 2013). In the context of the UNEP/SETAC Life Cycle Initiative a review of LCAs in packaging for food and beverage applications has recently been conducted, with the aim to provide practical guidance to support decision making in this sector (UNEP \& SETAC 2013). Particularly in the beverage packaging sector, LCA is widely used (von Falkenstein et al. 2010; Scipioni et al. 2013; Pasqualino et al. 2011; Mourad et al. 2008; Amienyo et al. 2012; Toniolo et al. 2013). LCA studies generally focus on packaging minimization, i.e. to reduce material use, leading to reduced environmental impacts, while maintaining the protection function of the packaging. However, according to Svanes et al. (2010) a long-term sustainability strategy for packaging should not be based on material minimization, but rather on packaging optimization, not only in terms of environmental sustainability, but also distribution costs, market acceptance and user friendliness.

Carlsberg Group, the fourth largest global brewery in the world, applies four different strategies in its sustainable packaging program (Carlsberg Group Annual Report 2016): Reduce (e.g. the weight of the packaging), Recycle (e.g. influence recycling rates and increase the amount of recycled content), Reuse (focus on the return and reuse of glass bottles), and Rethink (innovate within packaging and waste, by optimizing materials and channeling it into other products after its initial use). The first two approaches follow the eco-efficiency principle, advocating the adoption of LCA to identify the priority areas for reducing the environmental impacts of the company activities. According to LCA results, primary and secondary packaging account for approximately $45 \%$ of Carlsberg's total $\mathrm{CO}_{2}$ emissions (Carlsberg Group 2012), where the former is the packaging in 
direct contact with the beverage (e.g. an aluminum can) and the latter is the packaging used to group more units of primary packaging together (e.g. cardboard boxes). This has resulted in sustainable packaging being a key focus of Carlsberg's work within sustainability. Besides the LCA methodology, Carlsberg recently adopted a broader approach oriented towards product quality and innovation, i.e. the Cradle to $\mathrm{Cradle}^{\circledR}(\mathrm{C} 2 \mathrm{C})$ design framework. $\mathrm{C} 2 \mathrm{C}$ aims to increase the positive footprint of products by designing "eco-effective" solutions, i.e. maximizing the benefit to ecological and economical systems. The term "eco-effectiveness" was introduced to characterize an approach focusing on the development of products and industrial systems that maintain or enhance the quality and productivity of materials through subsequent use cycles (McDonough and Braungart 2002). The last two principles of Carlsberg's sustainable packaging agenda (reuse and rethink) are thus based on the eco-effectiveness principle. Moreover, the $\mathrm{C} 2 \mathrm{C}$ design framework inspired the creation in January 2014 of the Carlsberg Circular Community (CCC). This is a cooperation platform involving Carlsberg and a selection of global partners, aiming at rethinking the design and production of traditional packaging material, with the ambition to develop packaging products that are optimized for recycling and reuse, while retaining their quality and their value.

This paper aims at illustrating the opportunities and challenges in combining the use of LCA and $\mathrm{C} 2 \mathrm{C}$ certification in the beverage packaging sector, focusing on the case study of aluminum cans within the CCC. First, we summarize the outcomes of previous research on the combined use of eco-efficiency/LCA and eco-effectiveness/C2C in other sectors. Second, the case study of aluminum cans is introduced, to identify the learnings and limitations from the use of ecoeffectiveness and eco-efficiency approaches separately and to outline how the $\mathrm{C} 2 \mathrm{C}$ vision can inspire LCA. Third, we present a framework to integrate both approaches in the decision support for beverage packaging companies implementing a continuous loop packaging system. Finally we 
Niero et al. (2017) Journal of Industrial Ecology doi:10.1111/jiec.12554/full

discuss the challenges for companies that combine the use of LCA and eco-effectiveness approaches and how LCA can inspire the $\mathrm{C} 2 \mathrm{C}$ certification.

\section{$<$ heading level 1 $>$ Case studies of combined eco-efficiency/LCA and eco-effectiveness/C2C}

The complementarity of eco-efficiency and $\mathrm{C} 2 \mathrm{C}$ was previously discussed in more general terms by Bjørn and Hauschild (2013), and the usability of LCA in a C2C process was addressed by Bor et al. (2011). In their assessment framework for sustainable product design de Pauw and colleagues (2014a) propose two new elements to current life-cycle-based product assessment: assessing against conditions of sustainability, i.e. relative or absolute, and assessing "achievement", the extent to which these conditions of sustainability have been achieved. Moreover, the ability of the $\mathrm{C} 2 \mathrm{C}$ certification program to assess the "eco-effectiveness" of a design strategy has been questioned due to its main focus on the implementation of the $\mathrm{C} 2 \mathrm{C}$ strategy within an organization and support for communication and marketing of products that have already been developed (de Pauw et al. 2013).

The idea of having continuous loops of materials recently inspired Verghese and colleagues (2012) to define a more comprehensive packaging sustainability framework. According to their definition, in order to contribute to sustainable development, packaging needs to be effective in meeting its functional requirements; efficient in its use of materials, energy and water throughout its life cycle; cyclic in its use of renewable materials, and recoverability at end-of-life; and finally safe for people and the natural environment (Verghese et al. 2012). According to Rossi and colleagues (2006) LCA adopts a "tool-driven" approach to addressing environmental problems, i.e. it is a method to evaluate the environmental performance of a product, which inspires the stakeholders to make improvements to the product based on the conclusions generated by the LCA study. The C2C system adopts instead a "goal-driven" approach, since first the goals to be achieved are established, 
and then the tools and metrics needed to measure progress and help achieve those goals are developed. A goal of the $\mathrm{C} 2 \mathrm{C}$ vision is to generate cyclical, cradle-to-cradle "metabolisms" that enable materials to maintain their status as resources (upcycling). "Upcycling" refers to redesigning ingredients or additives so they improve the quality of materials with respect to maintaining or improving value in continuous loops. In order to identify the best upcycling option for a product, the so called "defined use" of the product has to be identified, i.e. the use of the product at each stage of the cascade considering the environment that the product is suited to (Bor et al. 2011).

In spite of the strong historical focus on environmental optimization of packaging systems, no studies of combined use of eco-efficiency/LCA and eco-effectiveness/C2C on packaging systems have been identified in literature. The only exception is one LCA study of a cradle-to-cradle cycle (biogas-to-bioplastic) generating biocompatible beverage packaging materials from methane emissions (Rostkowski et al. 2012).

However, the mutual influence of $\mathrm{C} 2 \mathrm{C}$ principles and LCA on each other has been addressed for other sectors. For the building sector, Silvestre et al. (2014) demonstrated that the eco-efficiency approach can be an important source of data for decision-making at the end-of-life of building materials, especially to identify whether the minimization of waste flows, the maximization of their reuse or recycling operations, or the increase of the recycled content maximizes their $\mathrm{C} 2 \mathrm{C}$ environmental performance. van Dijk and colleagues (2014) focused on three flows in the built environment, i.e. material, energy and water cycle and concluded that many companies in the building industry have difficulties to put the $\mathrm{C} 2 \mathrm{C}$ theory into practice, because among others the complexity of building projects. For the household sector, de Pauw and colleagues (2014), in the case of tableware and cutlery, and coffee machines, showed that $\mathrm{C} 2 \mathrm{C}$ can inspire an approach to product design that is distinct from what an LCA-based methodology would inspire. All previous 
Niero et al. (2017) Journal of Industrial Ecology doi:10.1111/jiec.12554/full

159

160

161

162

163

164

165

166

167

168

169

170

171

172

173

174

175

176

177

178

179

180

181

studies pointed out that further research is needed to support the different industries translating the C2C theory into practical implementation.

\section{$<$ heading level $1>$ The aluminum can case}

The following sections will present an overview of the main learnings and limits emerging from the use of eco-effectiveness and eco-efficiency approaches separately. These learnings are primarily derived from the experience of Carlsberg with the certification process of the aluminum cans for beer packaging (size 44, 50, $56.8 \mathrm{cl}$ ), which were $\mathrm{C} 2 \mathrm{C}$ certified at bronze level in the UK market in 2015. Moreover, the outcomes of previous studies performed by the authors are also taken into account (Niero et al. 2016a; Niero and Olsen 2016).

\section{$<$ heading level $2>$ Learnings from eco-effectiveness}

The eco-effectiveness concept of $\mathrm{C} 2 \mathrm{C}$ encompasses a series of strategies for generating healthy defined material flow metabolisms (Braungart et al. 2007). The components of a product, consisting of one or more materials, should be designed by intention to fit either within a biological or a technical cycle. Materials in the biological cycle are meant to be returned to the soil by composting or anaerobic digestion, while materials in the technical cycle are designed to be recovered and upgraded (Braungart and Engelfried 1992). The C2C vision with its three key principles "waste equals food", "use current solar income" and "celebrate diversity" (McDonough and Braungart 2002) aims to maximize the benefit to the ecological and economic systems through a shift towards a resource-effective economy, rather than just reduce the negative impacts of existing solutions. In such an economy humans are part of the ecological systems, and resources are retained within the economy when a product has reached the end of its use, so that they remain in 
productive use and create further value. $\mathrm{C} 2 \mathrm{C}$ has demonstrated to be a powerful framing for communicating and mobilizing societal and political action (Potting and Kroeze 2010), driving the circular economy.

With regard to $\mathrm{C} 2 \mathrm{C}$, a distinction should be made between Cradle to Cradle ${ }^{\circledR}$ as a vision oriented towards product quality and innovation based on the three abovementioned design principles, and the Cradle to Cradle Certified ${ }^{\mathrm{TM}}$ Product standard (hereafter $\mathrm{C} 2 \mathrm{C}$ certification program), which is a certification standard developed to document the degree of implementation of the $\mathrm{C} 2 \mathrm{C}$ concept within product manufacturing. The certification program, operating with five levels of accomplishment (basic, bronze, silver, gold, platinum), was conceived to allow companies to document their progress in applying the $\mathrm{C} 2 \mathrm{C}$ vision (Cradle to Cradle Products Innovation Institute 2016). Only platinum certified products are fully $\mathrm{C} 2 \mathrm{C}$ compliant, but so far only one C2C certified product worldwide has reached the platinum level. The only example of $\mathrm{C} 2 \mathrm{C}$ certification within the beverage packaging area hitherto concerns aluminum used for the manufacturing of beverage bottles and aluminum cans (http://www.c2ccertified.org/products/registry).

According to the $\mathrm{C} 2 \mathrm{C}$ terminology, aluminum is a "technical nutrient", i.e. a material that has the potential to remain safely in a closed-loop system of manufacture, recovery, and reuse (the technical metabolism), maintaining its highest value through many product life cycles (Braungart et al. 2007). Technical nutrients are used as "products of service", which are durable goods that provide a service to customers, such as the aluminum can does. Opposed to products of service are the so-called "products of consumption", i.e. made of biological nutrients.

Figure 1 presents the life cycle of an aluminum can, which is made of two components, the body, obtained typically from the 3004 alloy with a higher manganese content, and an upper part, including the lid and the pull tab, made by the 5182 alloy with a higher magnesium content and referred hereafter as "lid" (The University of Liverpool 2015). The lid is typically made from 
Niero et al. (2017) Journal of Industrial Ecology doi:10.1111/jiec.12554/full

primary aluminum alloy while the body is made from secondary aluminum alloy, adjusted with primary aluminum. Secondary aluminum is obtained from recycling operations, which include preprocessing, remelting and a final step of alloy adjustment, where the desired alloy composition is obtained (Niero and Olsen 2016).

Applying the five certification criteria (described in Table 1 and presented in Figure 1 with the exception of the social fairness criterion) several lessons were learned from the $\mathrm{C} 2 \mathrm{C}$ certification of the aluminum can. For material health $(\mathrm{MH})$ the ultimate goal is for all products to be manufactured using only those materials that have been optimized and do not contain any X or Grey assessed materials (i.e. toxic materials according to the $\mathrm{C} 2 \mathrm{C}$ certification). From the rating of the materials composing the can (i.e. body, lid, external varnishes and internal coatings) it turned out that substances even at ppm (i.e. part per million) level have an impact on value and recyclability. These substances often originate from additives or alloying elements giving the desired functional properties to the base material, as in the case of the lacquer. The material reutilization (MR) criterion is quantified by the so-called Material Reutilization Score (MRS). In the case of a material belonging to the technical cycle the MRS (see Equation 1) includes two variables: the $\%$ of the product considered recyclable (i.e. a material that can be recycled at least once after its initial use stage), and the \% of recycled content (RC) in the product (Cradle to Cradle Products Innovation Institute 2016):

$M R S=[2 \cdot(\%$ of the product considered recyclable $)+(\% \mathrm{RC})] / 3 \cdot 100$

In the case of the aluminum can a prerequisite for a high MRS is to ensure recyclability, e.g. in the case of closed loop through the optimization of the lacquer. The ease of removal of the lacquer indeed increases the recyclability of the Al scrap, whose value is directly dependent on its contamination level. However, the traditional de-lacquering is based on an energy intensive thermal process: the direct combustion of the paints results in the oxidation loss of aluminum as well as the 
Niero et al. (2017) Journal of Industrial Ecology doi:10.1111/jiec.12554/full

generation of toxic gas containing dioxin and furan (Li and Qiu 2013). The current MRS formula only takes into account the possibility to recycle the material at least once after its initial use stage and to a lesser extent the recycled content.

The last three certification criteria are at process level and concern renewable energy use and carbon management (RE\&CM), water stewardship (WS) and social fairness (SF) and to meet them, performance at production and organization levels need to be included in the optimization strategy. The learnings listed above are generic, and in the case of the Carlsberg's $\mathrm{C} 2 \mathrm{C}$ certified aluminum can, most of the learnings came from MH and MR criteria: the in-depth knowledge of its material composition (in terms of alloys) and the identification of optimized components (i.e. the lacquer) suggested the potential for a closed loop recycling.

\section{$<$ heading level $2>$ Learnings from eco-efficiency}

The eco-efficiency concept is based on "adding maximum value with minimum resource use and minimum pollution" (Huesemann, 2004). The focus in LCA is on reducing the environmental impacts of product/service and recycling is addressed only as one issue amongst several others. Reduction in environmental impacts has often been pursued through material efficiency either at the end-of-life of the product's first life, through product life extension (longer product life, refurbishment and remanufacturing, components reuse), or at the product design stage, e.g. reducing the amount of material in product manufacturing (Allwood et al. 2011). For beverage packaging, due to the short duration of its use stage, product life extension is not a viable option (except for returnable packaging) whereas focusing on the material use extension certainly is. A relevant aspect in this sector is the recyclability of the packaging material, which depends on both its technical recyclability, i.e. the ease with which it can be reprocessed and used to manufacture new products, and on the availability of facilities to collect, sort and reprocess the material (Verghese et al. 2012). 
Niero et al. (2017) Journal of Industrial Ecology doi:10.1111/jiec.12554/full

254 This double dependence calls for a closer collaboration between product designers and waste

255 management as a prerequisite to close the material loop (Ordoñez and Rahe 2013). According to

256 Bakker and colleagues (2014), the first item of a future research agenda for products in a circular

257 economy is to establish the optimal product life scenario. But which is the optimal beverage

258 packaging life scenario?

259 In a previous publication (Niero et al,. 2016a), we considered the case of a 33 cl aluminum

260 can in the UK market and compared the climate change impacts and cumulative energy demand

261 associated with achieving different levels of two C2C certification requirements (MR and RE). The

262 functional unit considered was the containment of $1 \mathrm{hl}$ of beer (where 1 hectolitre $=100$ litres). In

263 the calculation of the MRS we assumed that the \% of the product considered recyclable is constant

264 and equal to the total weight of the can minus the lacquer, i.e. 96.8\% (Niero and colleagues 2016a),

265 and varied the $\%$ of $\mathrm{RC}(50 \%, 65 \%, 100 \%)$ corresponding to a MRS value of $81.2,86.2$ and 97.9 ,

266 respectively. The LCA modelling was based on a pure Al flow (EAA 2013), using the default

267 ecoinvent v3.1 datasets for primary and secondary aluminum production (Moreno Ruiz et al. 2014).

268 The latter dataset is based on two sources: the European Aluminium Association 2005 LCI data and

269 the ecoinvent v2.2 dataset for the same activity (Moreno Ruiz et al. 2014). We concluded that,

270 limited to MR and RE, performance to a higher C2C certification level does not necessarily lead to

271 a reduction in the system's climate change impact (Niero et al. 2016a).

272 Figure 2 summarizes the results of the Life Cycle Impact Assessment (LCIA) of the

273 progressions in the $\mathrm{C} 2 \mathrm{C}$ certification level from bronze (B) to gold $(\mathrm{G})$ for the combinations of $\mathrm{MR}$

274 and RE criteria considered in the abovementioned study of the $33 \mathrm{cl}$ aluminum can (Niero and

275 colleagues 2016a). Results are shown for four impact categories: climate change (IPCC 2013),

276 freshwater ecotoxicity (USEtox, Rosenbaum et al. 2008), metal depletion and fossil depletion

277 (ReCiPe 2008, Goedkoop et al. 2009), in relative terms, i.e. normalized to the highest score for each 
impact category. Only the combinations relevant for the progressions of the bronze certified aluminum can towards higher certification levels are considered, i.e. gold and above for MR (where the can already meets the silver level requirements) and bronze and above for RE.

As the relative LCA results show (Figure 2) increasing the \% of renewable energy and the MRS result in a decrease of the potential environmental impacts in terms of climate change and fossil depletion. At the same time an increase in recycled content, which implies an intensification of recycling activities, seems to increase the metal depletion and freshwater ecotoxicity potentials, so there appears to be a trade-off. The increase in ecotoxicity is primarily due to the emissions of metals (mainly $\mathrm{Cu}$ ) during aluminum recycling, which dominate the freshwater toxicity impact (applying both recommended and interim characterization factors to cover as many emissions as possible) (Hauschild et al. 2013). The increase in metal depletion at increasing recycling rate is linked to the increase in the use of secondary aluminum, whose production is modelled by the default ecoinvent v3.1 dataset considering the extraction of copper and silicon as proxy alloying elements. These side-effects are not relevant in the case of aluminum recycling for cans and the observation points out the limitation of modelling aluminum processes with the default datasets based on average aluminum alloy composition, since the contribution to metal depletion of $\mathrm{Cu}$ is three orders of magnitude higher than the contribution of Al. When the actual alloy contribution is considered in the Life Cycle Inventory (LCI) modelling, results show that an increase of the recycling rate leads to lower impacts for climate change, resource depletion and human toxicity impacts (Niero and Olsen 2016).

\section{<heading level 2> Limits of a standalone use of eco-effectiveness and eco-efficiency} approaches 
The standalone use of eco-effectiveness and eco-efficiency approaches provides limited inputs to improve the design of the aluminum can system. The learnings provided by the $\mathrm{C} 2 \mathrm{C}$ certification mainly suggest improving the composition of the can with a focus at the material level. There is no clear indication on which actions should be prioritized to reach higher certification levels. On the other side, if LCA is used without a vision of continuous loop packaging system, i.e. focusing solely on the primary function of containment of the aluminum can, there is a risk of overlooking conceptually different design options for the packaging systems. This calls for a combination of both approaches in a systematic framework, able to provide decision makers in the packaging industry with a tool to prioritize actions towards the development of the most eco-efficient and ecoeffective packaging solutions.

\section{$<$ heading level 2>How can a C2C vision inspire LCA}

Table 2 summarizes how the $\mathrm{C} 2 \mathrm{C}$ vision can provide inspiration to each of the four methodological phases of the LCA (ISO 2006a, 2006b) in packaging optimization for the technical cycle.

The most relevant insights from the $\mathrm{C} 2 \mathrm{C}$ vision to LCA modelling are in the goal and scope definition and LCI modeling. The functional unit for an LCA on a beverage container is traditionally based on the service provided by the beverage container (e.g. to facilitate containment, distribution and storage of the beverage from the production site via retailers to consumers). This is valid when the scope of the study refers to only one life cycle, but in a circular economy perspective materials are meant to be used in continuous loops. We showed that to model multiple loops the functional unit should be defined including multiple co-functions, as introduced in the ILCD Handbook, Annex C (EC-JRC-IES 2011). Therefore, the functional unit should be "the containment of $1 \mathrm{hl}$ of beer and supply of resource after its use stage for 30 loops" (Niero and Olsen 2016). 
The actual material composition needs to be taken into account while addressing the use of aluminum in continuous loops. We challenged the prevailing LCI modelling of aluminum products, based on a pure aluminum flow, and performed the LCA considering both the components of an aluminum can, i.e. body and lid/tab, and their actual alloy compositions, showing that a closed product loop recycling, i.e. a can-to-can recycling is the best option from an environmental point of view, at least considering climate change impacts (Niero and Olsen 2016).

In the LCI modelling the main challenge is to model recycling over multiple life cycles. $\mathrm{C} 2 \mathrm{C}$ advocates for continuous material loop, which is different from closed material/product loop. In the ISO standards (ISO 2006b) recycling is methodologically a case of multi-functionality and it is modelled according to two factors: i) the next use of the material, distinguishing between closedloop recycling (material recycled in the same product system) and open-loop recycling (material recycled in a different product system), and ii) the changes in the inherent properties of materials, meaning that if the recycled material is used in another product system, then the closed loop approach can also be used for open-loop systems, as long as the inherent properties of the material are not changed. Both closed loop and open loop recycling approaches are potentially in accordance with circular economy principles. However, in the LCA community there is still no agreement on the way recycling processes should be modelled and different approaches are available (Allacker et al. 2014). The choice of the method to include recycling in LCA for aluminum cans does influence the results (van der Harst et al. 2016). An overestimated grade of the recovered materials can significantly inflate the perceived benefits gained from recycling. Nonetheless, most waste management LCA studies assume a 1:1 substitution ratio and/or quality similar to the substituted product, i.e. that $1 \mathrm{~kg}$ of secondary material substitutes $1 \mathrm{~kg}$ of primary material (Laurent et al. 2014b). However, even for metals this assumption might not be valid if the actual alloy composition is taken into account. The key aspect is to take into account the benefits of recovery of material not 
only from a quantitative, but also qualitative point of view. Further investigation is needed to identify how to quantify the downgrading of metals, even though some general guidance is provided, e.g. in the ILCD handbook (Annex C) (EC-JRC-IES 2010) in terms of quantification of the inherent technical properties of the secondary good or by the inclusion of a ratio between the quality of the secondary material and the quality of the primary material (Allacker et al. 2014).

\section{<heading level 1>Framework to combine eco-efficiency and eco-effectiveness for continuous}

\section{loop packaging systems}

Our framework to combine eco-efficiency and eco-effectiveness (see Figure 3) is based on a stepwise procedure aiming to assess the potentials for establishing continuous loop beverage packaging systems.

As a first step the optimal environmental life cycle scenario for beverage packaging is identified, both in terms of defined use and re-use. The distinction between the technical cycle and biological cycle can help in identifying the best use of the packaging. Inspired by the $\mathrm{C} 2 \mathrm{C}$ vision, the defined re-use of the packaging should be addressed in the functional unit definition. Apart from its primary function of containment, the function of an aluminum can is also to provide the aluminum scrap as secondary resource for subsequent product systems (Niero and Olsen 2016). The question is then "for how long should the co-function be provided"? The answer depends on the number of uses allowed for that material, which is linked to the definition of the best next use, i.e. identifying what "upcycling" means for packaging. When including the alloying elements in the LCA of the aluminum can, the closed product loop option emerged to be the best in terms of climate change performances (Niero and Olsen 2016).

Secondly, the two requirements at material level of the $\mathrm{C} 2 \mathrm{C}$ certification process, i.e. $\mathrm{MH}$ and $M R$, and the RE criterion are used to identify the limiting factors for the continuous use of materials 
Niero et al. (2017) Journal of Industrial Ecology doi:10.1111/jiec.12554/full

373 in multiple loops. For the aluminum can, can-to-can recycling is nowadays limited by the can

374 composition in terms of lacquer and by recycling operations, considering that aluminum scraps are

375 mixed (Cullen and Allwood 2013) and recycled aluminum is used for body production. Options to

376 separate body and lids in order to increase the recyclability of the can in multiple closed product

377 loops should be explored.

378 As a third step, alternative LCA scenarios of C2C certification are built to quantify the

379 environmental impacts of different options for the improvement of the packaging, encompassing

380 different improvement strategies, such as change in material composition (e.g. using a different

381 lacquer), use of renewable energy in product manufacturing and supply chain (see Niero et al.

382 2016a), increase of recycled content and recycling rate.

Finally, since circular economy is not only about resource scarcity and environmental impact,

but also economic benefit (Lieder and Rashid 2016), the business model of a closed loop supply has

to be included in the procedure. Our suggestion is to apply a green value network business model,

which supports a business model proposition formulated on a value network perspective,

incorporating both the economic and environmental perspectives, e.g. the framework developed by

Stewart et al. (in prep.). Such framework for green value network business model is built on the models, where "green" refers to the environmental aspect of sustainability. 
Our framework aims to connect upstream and downstream decisions in the value chain,

397 providing coherent incentives between producers, distributors, consumers and recyclers, and

398

399

400

401

402

403

404

405

406

407

408

409

410

411

412

413

414

415

416

417

418

419

ensuring a fair distribution of costs and benefits, through the definition of the green value network

business model, in accordance with the circular economy political agenda (EC 2014). The C2C

vision with the identification of a defined use scenario indeed allows aligning the interest of all

stakeholders towards a common goal. The inclusion of the defined use and re-use in the functional

unit definition of the LCA allows the alignment of eco-effectiveness principles and eco-efficiency

tools (see step 1 in Figure 3).

The need for interconnection is not only at the upstream level (e.g. coordination between can producers and beverage producers to optimize lacquer composition), but also downstream, for managing and controlling used materials and products for reuse by the firm, e.g. through reverse logistics systems (van der Wiel et al. 2012). The development of reverse logistics systems for packaging is constrained by the existing waste management system, which in some countries, e.g. the UK, prevents the separate collection of used beverage cans (UBCs). Therefore, a systems approach is required, with connections among all the stakeholders in the value chain, from suppliers to recyclers, and with repercussions at different levels, from technology (e.g. recycling technology) to logistics and waste management, as well as for different actors, i.e. customers and consumers, as summarized in Figure 3. The aim of joint actions such as the CCC, is indeed to engage suppliers and customers in initiatives with shared values, as well as consumers and new partnerships with relevant actors for a continuous loop product chain. On the top of the priority action list for the $\mathrm{CCC}$ is to design packaging for "zero contamination", since high quality recycling can only happen when the materials are not contaminated, either by other materials or through contamination by the content. For packaging belonging to the "technical cycle", such as the aluminum can, the ambition is to develop packaging solutions that are optimized for recycling and retain their quality and their 
value throughout multiple loops. Four types of actions form the backbones of the CCC (Carlsberg Group Annual Report 2016): i) assessment and optimization which is targeting suppliers such as the aluminum can producers; ii) communication and information oriented towards customers, e.g. using the $\mathrm{C} 2 \mathrm{C}$ certification scheme; iii) behavior change for consumers, e.g. through the participation to campaigns for UBC collection in events like festivals (see the "Every Can Counts initiative" in the UK) to educate end-users to dispose the packaging material in the appropriate collection bin and iv) involvement of partners aiming at packaging upcycling.

\section{<heading level $1>$ Recommendations and perspectives}

Eco-efficiency and eco-effectiveness approaches can be made operational by combining LCA and the $\mathrm{C} 2 \mathrm{C}$ certification program. The $\mathrm{C} 2 \mathrm{C}$ as a vision has a long term perspective and the $\mathrm{C} 2 \mathrm{C}$ certification scheme is the way to address the transient period towards a world of "platinum" $\mathrm{C} 2 \mathrm{C}$ products, where the $\mathrm{C} 2 \mathrm{C}$ certification levels represent different level of achievement of ecoeffectiveness. Our framework is based on a four step procedure to combine two tools, LCA and the $\mathrm{C} 2 \mathrm{C}$ certification program, in order to identify which actions should be prioritized for reducing the impacts or even increasing the (positive) effect of the company activities on society.

The framework was developed based on a case study of aluminum cans and the experience of Carlsberg with adopting both LCA and the $\mathrm{C} 2 \mathrm{C}$ certification program to produce both eco-efficient and eco-effective packaging. The main learnings from the $\mathrm{CCC}$ experience are that, to achieve an eco-efficient and eco-effective packaging, the can should be optimized by improving the composition of the lacquer, increasing the recycled content of the can, separating body and lids in order to increase the recyclability of the can in multiple closed product loops, and improving transparency in the materials composition, which is essential for high quality recycling. For aluminum cans the main recommendation from the developed framework is to ensure a system that 
Niero et al. (2017) Journal of Industrial Ecology doi:10.1111/jiec.12554/full

enables can-to-can recycling and to design packaging for "zero contamination". This is valid for the packaging system under study, characterized by high volumes, short use life, and existence of infrastructures for material collection. The suggested framework can be applied and adapted by any other company, familiar with both LCA and C2C certification program, to assure that the decision making process considers both eco-efficiency and eco-effectiveness.

\section{$<$ heading level $2>$ Challenges in combining eco-effectiveness and eco-efficiency}

One of the main challenges in the implementation of the $\mathrm{C} 2 \mathrm{C}$ certification scheme is the need for a closer cooperation with suppliers in order to gather the necessary data for the classification in the ABC-X assessment (see Table 1) and following optimization of substances as part of the MH certification. The shift to eco-effective industrial systems indeed requires to provide customers with information on how to deal with the product after its use period, as well as recyclers with information on appropriate material composition and dismantling processes (Braungart et al. 2007). Among all challenges for the implementation of circular economy strategies from a business perspective, product design plays a key role. This is especially true for packaging, which has to fit both product and its use environment and to take into account the increasingly complex packaging technology. A further complication is due to the increasing web of material producers, packaging component manufacturers, packaging equipment suppliers, users, retailers and waste recovery facilities and reprocessors that might have different priorities and interests. The $\mathrm{C} 2 \mathrm{C}$ certification is performed on the product level, e.g. in the case of aluminum cans for the primary packaging, i.e. the materials in direct contact with the product, so neglecting the secondary and tertiary packaging.

Combining the $\mathrm{C} 2 \mathrm{C}$ certification with LCA provides a further option to avoid the risk of suboptimization of the primary packaging at the expense of secondary or tertiary packaging. 
However, we are aware that in coupling LCA with the eco-effectiveness approach there are data limitations, e.g. on specification of materials and recycling operations, which may lead to simplification. In the ideal case we would have time and data to go much deeper in terms of what is the real material composition including additives, how it can be recycled, what is the composition of the recycled material and what are its potential and real applications, but in practice there is always a trade-off between the wish for precision and simplification (Zamagni et al. 2012).

\section{$<$ heading level 2>How can LCA inspire C2C certification}

Elements for improving the $\mathrm{C} 2 \mathrm{C}$ certification program can be found for most of the certification requirements. For MR, efforts should be put on increasing the recycling rate to increase the availability of recycled aluminum. The current formula to calculate the MRS only takes into account the possibility to recycle the material at least once after its initial use stage, which might not reflect the actual recycling routine for the considered material. Efforts to improve the separate collection of materials should be rewarded and accounted for in this requirement.

As suggested by Bjørn and Hauschild (2013) in cases where there is a trade-off between the $\mathrm{C} 2 \mathrm{C}$ requirements for energy and material consumption, the environmental impacts associated with the energy consumption should also be considered. We recently provided an overview of the limitations of the current RE\&CM requirement, mainly focusing on use of energy in the manufacturing stage We considered the introduction of a broader RE perspective covering the life cycle, and our results showed that increasing the share of RE in the primary aluminum production from a full life cycle perspective can greatly increase the environmental benefits brought up by the C2C certification, not only for climate change, but for the broader range of impact categories (Niero et al. 2016b). 
Niero et al. (2017) Journal of Industrial Ecology doi:10.1111/jiec.12554/full

A last suggestion for improvement of the $\mathrm{C} 2 \mathrm{C}$ certification program refers to the water stewardship (WS) criterion, which provides information on the quantitative and qualitative aspects of water, but could benefit from being integrated with an impact assessment method considering the scarcity aspect, e.g. through a water scarcity footprint assessment, see e.g. Boulay et al. (2013).

\section{Acknowledgments}

The authors would like to thank Carlsberg Foundation for funding the postdoc project 'Design of Cradle to Cradle ${ }^{\circledR}$ - Inspired System for Beer Beverage Packaging”, as well as all people in Carlsberg Group who were involved in the discussion and data collection, in particular Håkon Langen, Eskild Andersen and Renil Manat. The feedback received by Katja Hansen from EPEA on an earlier version of the manuscript is highly appreciated. The authors further thank the editor and two anonymous reviewers whose comments and suggestions helped improving the manuscript.

\section{References}

Allacker, K., F. Mathieux, S. Manfredi, N. Pelletier, C. De Camillis, F. Ardente, and R. Pant. 2014. Allocation solutions for secondary material production and end of life recovery: Proposals for product policy initiatives. Resources, Conservation and Recycling 88: 1-12. http://linkinghub.elsevier.com/retrieve/pii/S0921344914000834.

Allwood, J.M., M.F. Ashby, T.G. Gutowski, and E. Worrell. 2011. Material efficiency: A white paper. Resources, Conservation and Recycling 55(3): 362-381. http://linkinghub.elsevier.com/retrieve/pii/S0921344910002405.

Amienyo, D., H. Gujba, H. Stichnothe, and A. Azapagic. 2012. Life cycle environmental impacts of carbonated soft drinks. The International Journal of Life Cycle Assessment 18(1): 77-92. http://link.springer.com/10.1007/s11367-012-0459-y.

Bakker, C., F. Wang, J. Huisman, and M. den Hollander. 2014. Products that go round: exploring product life extension through design. Journal of Cleaner Production 69: 10-16. http://linkinghub.elsevier.com/retrieve/pii/S0959652614000419. 
Niero et al. (2017) Journal of Industrial Ecology doi:10.1111/jiec.12554/full

519

520

521

522

523

524

525

526

527

528

529

530

531

532

533

534

535

536

537

538

539

540

541

542

543

544

545

546

547

548

549

550

551

552

553

554

555

556

557

558

559

560

Bjørn, A. and M.Z. Hauschild. 2013. Absolute versus Relative Environmental Sustainability. Journal of Industrial Ecology 17(2): 321-332. http://doi.wiley.com/10.1111/j.15309290.2012.00520.x.

Bocken, N.M.P., S.W. Short, P. Rana, and S. Evans. 2014. A literature and practice review to develop sustainable business model archetypes. Journal of Cleaner Production 65: 42-56. http://dx.doi.org/10.1016/j.jclepro.2013.11.039.

Bor, A.-M., K. Hansen, A. Alan Riviere, C. Alvarado, and W. van den Wittenboer. 2011. Usability of Life Cycle assessment for Cradle to Cradle purposes. NL Agency, Utrecht.

Boulay, A.-M.M., A.Y. Hoekstra, and S. Vionnet. 2013. Complementarities of Water-Focused Life Cycle Assessment and Water Footprint Assessment. Environ. Sci. Technol., 47(21): 1192611927. http://pubs.acs.org/doi/abs/10.1021/es403928flnhttp://pubs.acs.org/doi/full/10.1021/es403928f Inhttp://www.waterfootprint.org/?page=files/Publications.

Braungart, M. and J. Engelfried. 1992. An "intelligent product system" to replace "waste management." Fresenius Environmental Bulletin, 1(9), 1(9): 613-619.

Braungart, M., W. McDonough, and A. Bollinger. 2007. Cradle-to-cradle design: creating healthy emissions - a strategy for eco-effective product and system design. Journal of Cleaner Production 15(13-14): 1337-1348.

http://linkinghub.elsevier.com/retrieve/pii/S0959652606002587. Accessed November 10, 2014.

Carlsberg Group. 2012. The Carlsberg Group Corporate Social Responsibility Report 2012.

Carlsberg Group Annual Report. 2016. Carlsberg Group annual report 2015.

Cradle to Cradle Products Innovation Institute. 2016. Cradle to Cradle Certified Product Standard Version 3.1. http://s3.amazonaws.com/c2c-

website/resources/certification/standard/C2CCertified_Product_Standard_V3_Nov_4_2013.pd f.

Cullen, J.M. and J.M. Allwood. 2013. Mapping the global flow of aluminium: from liquid aluminium to End-Use goods. Environmental Science \& Technology 47: 3057-3064. http://www.ncbi.nlm.nih.gov/pubmed/23167601.

Dijk, S. van, M. Tenpierik, and A. van den Dobbelsteen. 2014. Continuing the building's cycles: A literature review and analysis of current systems theories in comparison with the theory of Cradle to Cradle. Resources, Conservation and Recycling 82: 21-34. http://linkinghub.elsevier.com/retrieve/pii/S0921344913002140.

EC. 2014. COMMUNICATION FROM THE COMMISSION TO THE EUROPEAN PARLIAMENT, THE COUNCIL, THE EUROPEAN ECONOMIC AND SOCIAL COMMITTEE AND THE COMMITTEE OF THE REGIONS Towards a circular economy: A zero waste programme for Europe. COM(2014) 398 final.

EC. 2015. COM (2015) 614 Communication from the Commission to the European Parliament, the Council, the European Economic and Social Committee and the Committee of the Regions. Closing the loop - An EU action plan for the Circular Economy. http://ec.europa.eu/environment/circular-economy/index_en.htm.

EC-JRC-IES. 2010. ILCD Handbook - General guide on LCA - Detailed guidance. Euroepan 
Niero et al. (2017) Journal of Industrial Ecology doi:10.1111/jiec.12554/full

Commission. Joint Research Centre. Institute for Environment and Sustainability. First edit. Vol. 15. European Union.

EC-JRC-IES. 2011. International Reference Life Cycle Data System (ILCD) HandbookRecommendations for Life Cycle Impact Assessment in the European context. First edit. Luxemburg: EUR 24571 EN. Publications Office of the European Union.

EMF. 2013. Towards the circular economy. Opportunities for the consumer goods sector. Ellen MacArthur Foundation.

EAA. 2013. Environmental Profile Report for the European Aluminium Industry April 2013- Data for the year 2010 Life Cycle Inventory data for aluminium production and transformation processes in Europe. European Alluminium Association.

Falkenstein, E. von, F. Wellenreuther, and A. Detzel. 2010. LCA studies comparing beverage cartons and alternative packaging: can overall conclusions be drawn? The International Journal of Life Cycle Assessment 15(9): 938-945. http://link.springer.com/10.1007/s11367010-0218-x.

Goedkoop, M., R. Heijungs, M. Huijbregts, A. De Schryver, J. Struijs, and van Z. R. 2009. ReCiPe 2008, A life cycle impact assessment method which comprises harmonised category indicators at the midpoint and the endpoint level. http://www.lcia-recipe.net.

Greenblue. 2011. Definition of Sustainable Packaging. http://sustainablepackaging.org/uploads/Documents/Definition of Sustainable Packaging.pdf.

Hannon, B. 1972. System energy and recycling: a study of the container industry. American Society of Mechanical Engineers, New York.

Harst, E. van der, J. Potting, and C. Kroeze. 2016. Comparison of different methods to include recycling in LCAs of aluminium cans and disposable polystyrene cups. Waste Management 48: 565-583. http://www.sciencedirect.com/science/article/pii/S0956053X15301367.

Hauschild, M.Z., M. Goedkoop, J. Guinée, R. Heijungs, M. Huijbregts, O. Jolliet, M. Margni, and colleagues. 2013. Identifying best existing practice for characterization modeling in life cycle impact assessment. The International Journal of Life Cycle Assessment 18(3): 683-697. http://link.springer.com/10.1007/s11367-012-0489-5.

Hopewell, J., R. Dvorak, and E. Kosior. 2009. Plastics recycling: challenges and opportunities. Philosophical Transactions of the Royal Society of London. Series B, Biological Sciences 364(1526): 2115-26. http://www.pubmedcentral.nih.gov/articlerender.fcgi?artid=2873020\&tool=pmcentrez\&render type $=$ abstract.

IPCC. 2013. Climate Change 2013 The Physical Science Basis Working Group I Contribution to the Fifth Assessment Report of the Intergovernmental Panel on Climate Change Edited by. Ed. by T. F. Stocker, D. Qin, G.-K. Plattner, Tignor M., S.K. Allen, J. Boschung, A. Nauels, Y. Xia, V. Bex, and P.M. Midgley. Cambridge University Press, Cambridge, United Kingdom and New York, NY, USA, 1535pp.

ISO. 2006a. Environmental management. Life cycle assessment. Principle and framework. ISO 14040:2006. Vol. 44. Geneva, Switzerland.

ISO. 2006b. Environmental management. Life cycle assessment. Requirements and guidelines. ISO 14044:2006. Vol. 44. Geneva, Switzerland. 
Niero et al. (2017) Journal of Industrial Ecology doi:10.1111/jiec.12554/full

603

604

605

606

607

608

609

610

611

612

613

614

615

616

617

618

619

620

621

622

623

624

625

626

627

628

629

630

631

632

633

634

635

636

637

638

639

640

641

642

643

644

Laurent, A., J. Clavreul, A. Bernstad, I. Bakas, M. Niero, E. Gentil, T.H. Christensen, and M.Z. Hauschild. 2014. Review of LCA studies of solid waste management systems--part II: methodological guidance for a better practice. Waste Management (New York, N.Y.) 34(3): 589-606. http://www.ncbi.nlm.nih.gov/pubmed/24388596.

Laurent, A. and M.Z. Hauschild. 2015. Normalization. In Life Cycle Impact Assessment, LCA Compendium - The Complete World of Life Cycle Assessment, ed. by M.Z. Hauschild and M.A.J. Huijbregts, 271-300. Dordrecht, NL: Springer. http://www.springerlink.com/index/M5342P55737M7016.pdflnhttp://www.cs.ucsb.edu/ chon g/290N-W10/EPAonLCA2006.pdf.

Li, N. and K. Qiu. 2013. Study on delacquer used beverage cans by vacuum pyrolysis for recycle. Environmental Science \& Technology 47(20): 11734-8. http://www.ncbi.nlm.nih.gov/pubmed/24070094.

Lieder, M. and A. Rashid. 2016. Towards Circular Economy implementation: A comprehensive review in context of manufacturing industry. Journal of Cleaner Production 115: 36-51. http://linkinghub.elsevier.com/retrieve/pii/S0959652615018661.

McDonough, W. and M. Braungart. 2002. Cradle to cradle. North Point Press. New York.

Moreno Ruiz, E., T. Lévová, G. Bourgault, and G. Wernet. 2014. Documentation of changes implemented in ecoinvent Data 3.1. Ecoinvent. Zurich.

Mourad, A.L., E.E.C. Garcia, G.B. Vilela, and F. Von Zuben. 2008. Environmental Effects from a Recycling Rate Increase of Cardboard of Aseptic Packaging System for Milk Using Life Cycle Approach. International Journal of Life Cycle Assessment 13(2): 140-146.

Niero, M., A.J. Negrelli, S.B. Hoffmeyer, S.I. Olsen, and M. Birkved. 2016a. Closing the loop for aluminium cans: Life Cycle Assessment of progression in Cradle-to-Cradle certification levels. Journal of Cleaner Production 126: 352-362. http://dx.doi.org/10.1016/j.jclepro.2016.02.122.

Niero, M. and S.I. Olsen. 2016. Circular economy : to be or not to be in a closed product loop? A Life Cycle Assessment of aluminium cans with inclusion of alloying elements. Resources Conservation and Recycling 114: 18-31. http://dx.doi.org/10.1016/j.resconrec.2016.06.023.

Niero, M., S.I. Olsen, and A. Laurent. 2016b. Renewable energy and carbon management in the Cradle- to-Cradle certification: Limitations and opportunities. Journal of Industrial Ecology (Accepted with Minor Revision) June.

Ordoñez, I. and U. Rahe. 2013. Collaboration between design and waste management: Can it help close the material loop? Resources, Conservation and Recycling 72: 108-117. http://linkinghub.elsevier.com/retrieve/pii/S0921344913000037.

Pasqualino, J., M. Meneses, and F. Castells. 2011. The carbon footprint and energy consumption of beverage packaging selection and disposal. Journal of Food Engineering 103(4): 357-365. http://linkinghub.elsevier.com/retrieve/pii/S026087741000542X.

Pauw, I.C. de, P. Kandachar, and E. Karana. 2014a. Assessing sustainability in nature-inspired design. International Journal of Sustainable Engineering 8(1): 5-13. http://www.tandfonline.com/doi/abs/10.1080/19397038.2014.977373. Accessed March 18, 2015.

Pauw, I.C. de, E. Karana, P. Kandachar, and F. Poppelaars. 2014b. Comparing Biomimicry and Cradle to Cradle with Ecodesign: a case study of student design projects. Journal of Cleaner 
Niero et al. (2017) Journal of Industrial Ecology doi:10.1111/jiec.12554/full

Production 78: 174-183. http://linkinghub.elsevier.com/retrieve/pii/S0959652614004405.

Pauw, I.C. de, E. Karana, and P. V Kandachar. 2013. Cradle to cradle in product development: A case study of closed-loop design. In 20th CIRP International Conference on Life Cycle Engineering, Singapore, 2013, 47-52 BT-Re-engineering manufacturing for susta. http://www.springer.com/engineering/mechanical+engineering/book/978-981-4451-47-5.

Potting, J. and C. Kroeze. 2010. Cradle to cradle: old wine or new spirits? Integrated Environmental Assessment and Management 6(2): 315-317. http://doi.wiley.com/10.1002/ieam.44.

Rosenbaum, R.K., T.M. Bachmann, L.S. Gold, M. a. J. Huijbregts, O. Jolliet, R. Juraske, A. Koehler, and colleagues. 2008. USEtox - the UNEP-SETAC toxicity model: recommended characterisation factors for human toxicity and freshwater ecotoxicity in life cycle impact assessment. The International Journal of Life Cycle Assessment 13(7): 532-546. http://link.springer.com/10.1007/s11367-008-0038-4. Accessed February 19, 2014.

Rossi, M., S. Charon, G. Wing, and J. Ewell. 2006. Design for the Next Generation Incorporating Cradle-to-Cradle Design into Herman Miller Products. Journal of Industrial Ecology 10(4): $193-210$.

Rostkowski, K.H., C.S. Criddle, and M.D. Lepech. 2012. Cradle-to-Gate Life Cycle Assessment for a Cradle-to-Cradle Cycle: Biogas-to-Bioplastic (and Back). Environmental Science \& Technology 46: 9822-9829.

Sala, S., F. Farioli, and A. Zamagni. 2012. Progress in sustainability science: lessons learnt from current methodologies for sustainability assessment: Part 1. The International Journal of Life Cycle Assessment 18(9): 1653-1672. http://link.springer.com/10.1007/s11367-012-0508-6.

Scipioni, A., M. Niero, A. Mazzi, A. Manzardo, and S. Piubello. 2013. Significance of the use of non-renewable fossil CED as proxy indicator for screening LCA in the beverage packaging sector. International Journal of Life Cycle Assessment 18: 673-682.

Sustainable Packaging Alliance. 2002. Towards Sustainable Packaging A Discussion Paper. http://www.sustainablepack.org/database/files/filestorage/Towards Sustainable Packaging.pdf.

Svanes, B.E., M. Vold, H. Møller, M.K. Pettersen, H. Larsen, and O.J. Hanssen. 2010. Sustainable Packaging Design : a Holistic Methodology for Packaging Design. Packaging Technology and Science 23(February): 161-175.

The University of Liverpool. 2015. Aluselect. http://aluminium.matter.org.uk/aluselect/06_wrought_comp.asp. Accessed September 15, 2015.

Toniolo, S., A. Mazzi, M. Niero, F. Zuliani, and A. Scipioni. 2013. Comparative LCA to evaluate how much recycling is environmentally favourable for food packaging. Resources, Conservation and Recycling 77: 61-68.

UNEP. 2011. Decoupling natural resource use and environmental impacts from economic growth, A Report of the Working Group on Decoupling to the International Resource Panel. Ed. by M. Fischer-Kowalski, M. Swilling, E.U. von Weizsäcker, Y. Ren, Y. Moriguchi, W. Crane, F. Krausmann, and colleagues.

UNEP \& SETAC. 2013. Analysis of Life Cycle Assessment in Packaging for Food \& Beverage Applications. United Nations Environmental Programme Society of Environmental Toxicology and Chemistry Life Cycle Initiative. 
Verghese, K., H. Lewis, and L. Fitzpatrick. 2012. Packaging for Sustainability. Springer-Verlag London Limited.

Wever, B.R. and J. Vogtländer. 2013. Eco-efficient Value Creation: An Alternative Perspective on Packaging and Sustainability. Packaging Technology 26(June 2012): 229-248.

Wiel, A. van der, B. Bossink, and E. Masurel. 2012. Reverse logistics for waste reduction in cradleto-cradle-oriented firms : waste management strategies in the Dutch metal industry. Int. J. Technology Management 60: 96-113.

Zamagni, A., P. Masoni, P. Buttol, A. Raggi, and R. Buonamici. 2012. Finding Life Cycle Assessment Research Direction with the Aid of Meta-Analysis. Journal of Industrial Ecology 16(SUPPL.1): 39-52. 
699 About the authors

700 Monia Niero is a Researcher at the Division for Quantitative Sustainability Assessment (QSA), 701 Department of Management Engineering at the Technical University of Denmark (Kgs. Lyngby, 702 Denmark), Michael Z. Hauschild is professor and head of the QSA Division, Department of 703 Management Engineering at the Technical University of Denmark (Kgs. Lyngby, Denmark), Simon B. Hoffmeyer is Director, Group Sustainability, at Carlsberg Group (Copenhagen, Denmark) and 705 Stig I. Olsen is Associate Professor at the QSA Division, Department of Management Engineering 706 at the Technical University of Denmark (Kgs. Lyngby, Denmark). 


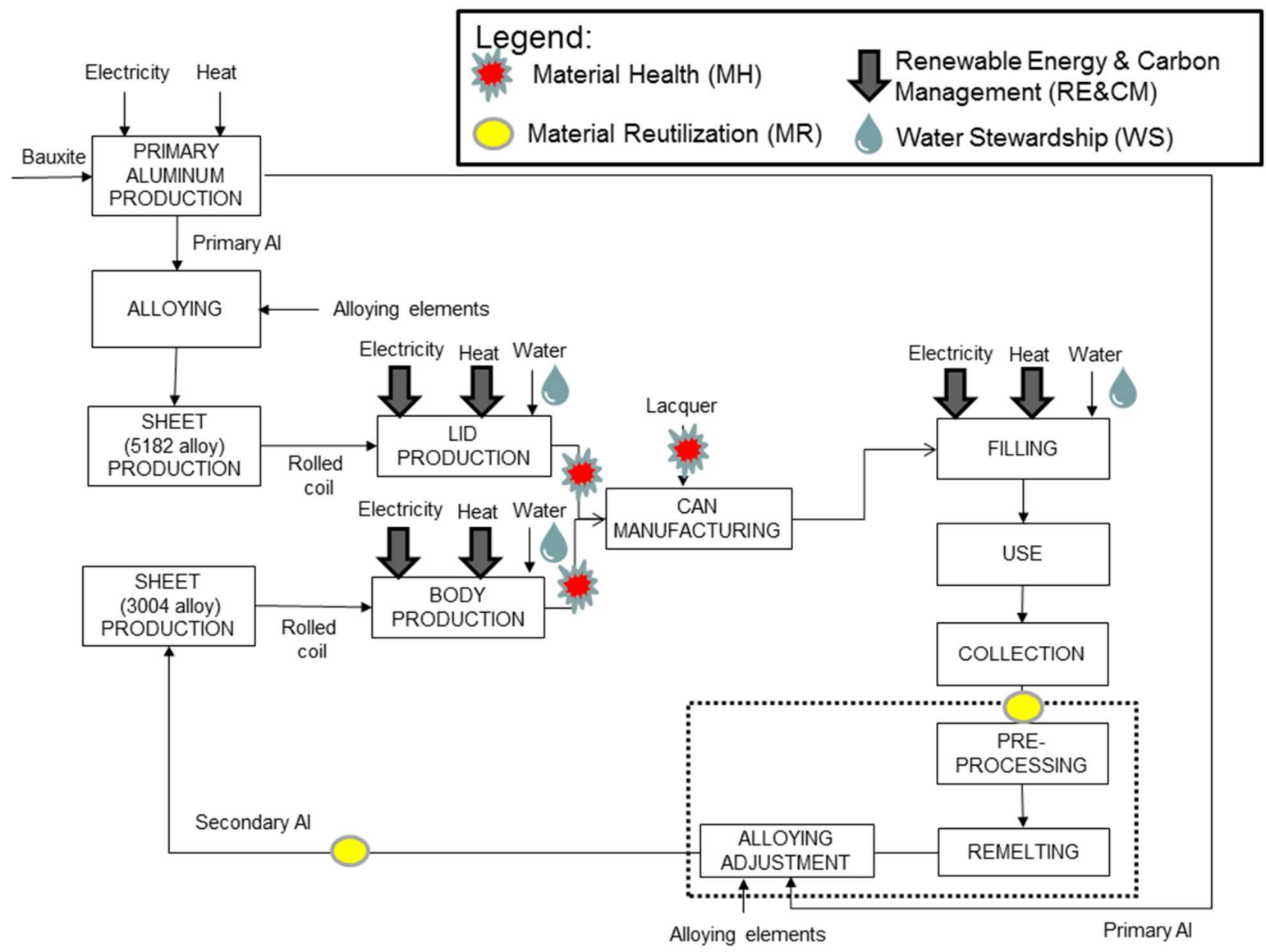

Figure 1 System boundaries of the life cycle of aluminum can, from raw material extraction (i.e. primary aluminum production) to the end of life, including recycling (represented by the dashed line including pre-processing, remelting and alloying adjustment). The consideration of 4 out of the 5 Cradle-to-Cradle (C2C) certification criteria is indicated at the relevant points in the life cycle - material health (MH), material reutilization (MR), renewable energy and carbon management (RE\&CM), and water stewardship (WS). 


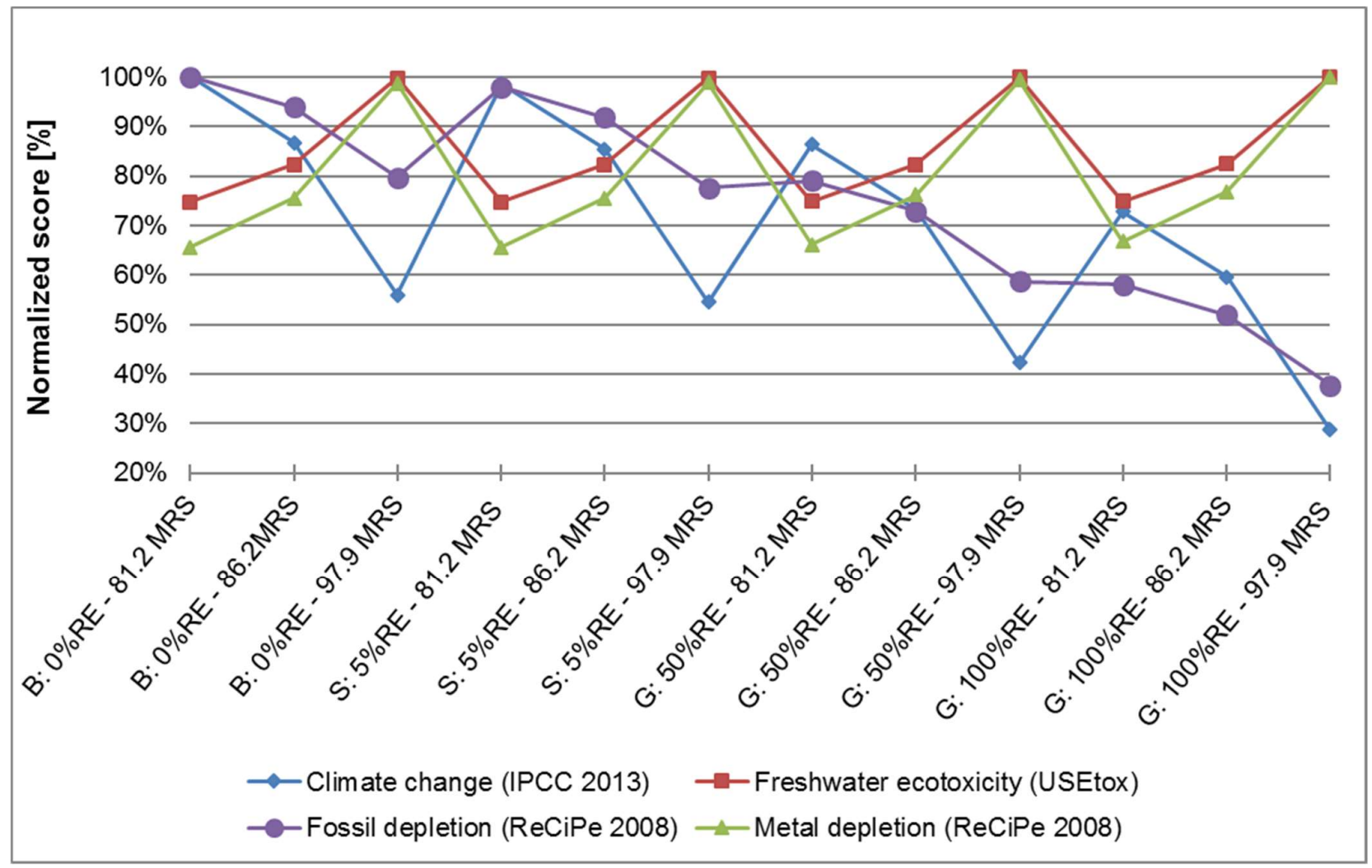

Figure 2: Normalized Life Cycle Impact Assessment (LCIA) scores of progression in Cradleto-Cradle (C2C) certification from bronze (B) to silver (S) to gold (G) based on the Life Cycle Inventory (LCI) modelling presented in (Niero et al. 2016a) for climate change, freshwater ecotoxicity metal depletion and fossil depletion. The LCIA scores are normalized using normalization by maximum approach (Laurent and Hauschild 2015), where each impact scores is dived by the maximum value of the different scenarios (as \%). Scenarios were built varying two parameters, \% RE (renewable energy) and the material reutilization score (MRS), calculated according to Equation 1 with constant \% of material considered recycled and increasing \% recycled content (RC, i.e. $50 \%, 65 \%, 100 \%)$ corresponding to a MRS value of 81.2, 86.2 and 97.9, respectively. 


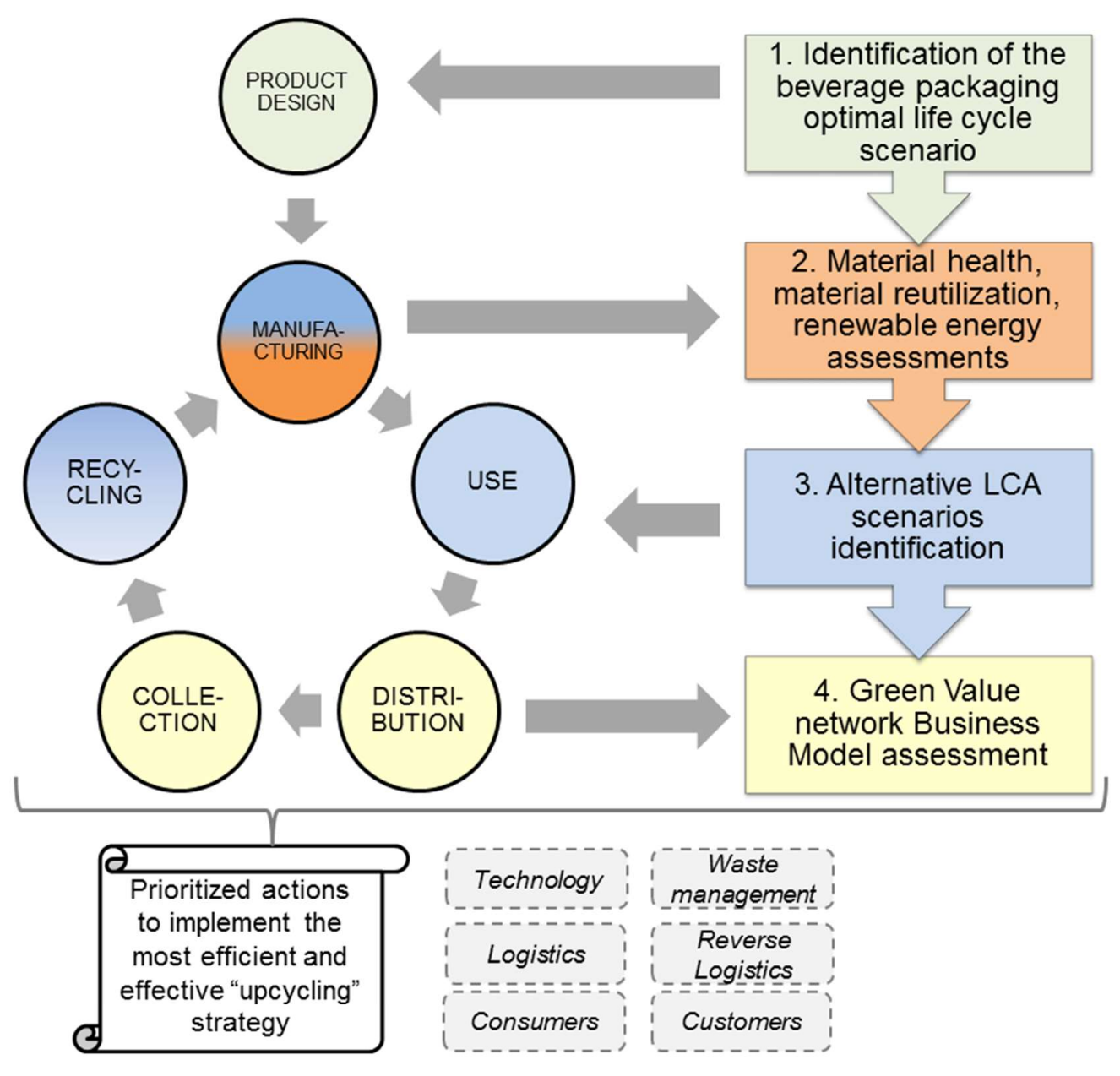
Cycle Assessment methodology. 
Niero et al. (2017) Journal of Industrial Ecology doi:10.1111/jiec.12554/full

Table 1: Description of $\mathrm{C} 2 \mathrm{C}$ certification criteria and main learnings gained by the Carlsberg Circular criterion the level reached by the aluminum can considered in the case study.

\begin{tabular}{|c|c|c|}
\hline $\begin{array}{l}\text { C2C certification } \\
\text { criterion }\end{array}$ & $\begin{array}{l}\text { Description (Cradle to Cradle Products } \\
\text { Innovation Institute 2016) }\end{array}$ & Learnings from CCC \\
\hline $\begin{array}{l}\text { MH: Material Health } \\
\text { (Bronze) }\end{array}$ & $\begin{array}{l}\text { Provide material assessment ratings (ABC- } \\
\mathrm{X} \text { assessment) based on the hazards of } \\
\text { chemicals in products and their relative } \\
\text { routes of exposure during the intended (and } \\
\text { highly likely unintended) use and end-of- } \\
\text { use product phases. }\end{array}$ & $\begin{array}{l}\text { Substances even at ppm level, such } \\
\text { as the lacquer, have an impact on } \\
\text { value and recyclability }\end{array}$ \\
\hline $\begin{array}{l}\text { MR: Material } \\
\text { Reutilization (Silver) }\end{array}$ & $\begin{array}{l}\text { Provide quantitative measure of the } \\
\text { product's design for recyclability (technical } \\
\text { cycle) and/or compostability (biological } \\
\text { cycle) }\end{array}$ & $\begin{array}{l}\text { Ensuring recyclability, e.g. through } \\
\text { the optimization of the lacquer, is a } \\
\text { prerequisite for high recycled } \\
\text { content }\end{array}$ \\
\hline $\begin{array}{l}\text { RE\&CM: Renewable } \\
\text { Energy \& Carbon } \\
\text { Management } \\
\text { (Bronze) }\end{array}$ & $\begin{array}{l}\text { Provide quantitative measure of the share of } \\
\text { renewable energy utilized in the } \\
\text { manufacture of the product }\end{array}$ & $\begin{array}{l}\text { Performance at production level } \\
\text { needs to be included in the } \\
\text { optimization strategy }\end{array}$ \\
\hline $\begin{array}{l}\text { WS: Water } \\
\text { Stewardship } \\
\text { (Bronze) }\end{array}$ & $\begin{array}{l}\text { Provide quantitative and qualitative } \\
\text { measure of water usage and water effluent } \\
\text { related directly to manufacture of the } \\
\text { certified product }\end{array}$ & $\begin{array}{l}\text { Performance at production level } \\
\text { needs to be included in the } \\
\text { optimization strategy }\end{array}$ \\
\hline $\begin{array}{l}\text { SF: Social Fairness } \\
\text { (Bronze) }\end{array}$ & $\begin{array}{l}\text { Provide qualitative measure of impact of } \\
\text { product manufacture on people and } \\
\text { communities }\end{array}$ & $\begin{array}{l}\text { Performance at organization level } \\
\text { needs to be included in the } \\
\text { optimization strategy }\end{array}$ \\
\hline
\end{tabular}

735

736

737 
Table 2: Main challenges and opportunities for including the C2C vision in each step of LCA methodology in the case of "products of service" belonging to the technical metabolism.

\begin{tabular}{|c|c|c|}
\hline Step & Challenge & Opportunity \\
\hline $\begin{array}{l}\text { 1. Goal and scope } \\
\text { definition }\end{array}$ & $\begin{array}{l}\text { - Include secondary function of the } \\
\text { packaging in the functional unit } \\
\text { definition }\end{array}$ & $\begin{array}{l}\text { - Identification of the least } \\
\text { environmentally impacting option } \\
\text { considering multiple loops } \\
\text { - Use scenario analysis to test the } \\
\text { influence of possible design choices }\end{array}$ \\
\hline $\begin{array}{l}\text { 2. Life Cycle } \\
\text { Inventory (LCI) }\end{array}$ & $\begin{array}{l}\text { - Identify how much primary secondary } \\
\text { is substituted by secondary material } \\
\text { - Data availability }\end{array}$ & $\begin{array}{l}\text { - Take into account the benefit of } \\
\text { recovery of material not only from a } \\
\text { quantitative, but also qualitative point of } \\
\text { view }\end{array}$ \\
\hline $\begin{array}{l}\text { 3. Life Cycle } \\
\text { Impact Assessment } \\
\text { (LCIA) }\end{array}$ & - Avoid burden shifting & - Include all relevant impact categories \\
\hline $\begin{array}{l}\text { 4. Life Cycle } \\
\text { Interpretation }\end{array}$ & $\begin{array}{l}\text { - Include the learnings from LCA not } \\
\text { only ex-post, but also ex-ante, i.e. at the } \\
\text { early design phase }\end{array}$ & $\begin{array}{l}\text { - Add further elements to support the } \\
\text { decision making process, e.g. } \\
\text { implications for the supply chain, } \\
\text { business models }\end{array}$ \\
\hline
\end{tabular}

740 